\title{
Comparison of 3 techniques for monitoring use of western wheatgrass
}

\author{
LACEY E. HALSTEAD, LARRY D. HOWERY, AND GEORGE B. RUYLE
}

Authors are former graduate research assistant, assistant rangeland management specialist, and rangeland management specialist, School of Renewable Natural Resources, The University of Arizona, Tucson, Ariz., 85721. Current address for senior author is Nuisance Wildlife Coordinator, New Mexico Department of Game and Fish, 408 Galisteo, Santa Fe, N.M. 87504.

\section{Abstract}

Forage use data can help rangeland and wildlife managers make informed decisions. However, managers need to know if forage use techniques that are commonly used to estimate ungulate herbivory under field conditions produce comparable results. The objective of this 2-year study was to directly compare forage use measurements obtained via the paired-plot method and 2 height-weight methods (using on-site height-weight curves and the pre-established United States Forest Service height-weight gauge). In June, July, and October of 1997 and 1998, we measured forage use of western wheatgrass (Pascopyrum smithii Rydb.) by cattle (Bos tau rus L.) and wild ungulates, mainly elk (Cervus elaphus L.). On-site height-weight curves and the USFS gauge consistently produced lower estimates (overall means $=8$ and $7 \%$, respectively) than the paired-plot method (overall mean $=31 \%$ ). Height-weight estimates did not differ $(P>0.05)$ when calculated with either on-site curves or the USFS gauge. Within sampling areas, paired-plot estimates were relatively more precise (mean $\mathrm{CV}=63 \%$ ) than on-site curves (mean CV $=238 \%$ ) or the USFS gauge $($ mean CV $=271 \%)$. Selective grazing likely contributed to higher CVs for heightweight techniques. Our findings are important for rangeland and wildlife managers because the forage monitoring technique they use may influence the results obtained and, consequently, grazing management and wildlife harvest decisions. Managers should ensure that chosen monitoring techniques provide an appropriate evaluation of management goals and objectives.

Key Words: Arizona, height-weight, herbivory, paired-plot, stubble height

As demands upon rangeland resources increase, managers must monitor rangeland uses and resource responses to satisfy a growing number and variety of stakeholders. Methods such as the paired-plot and height-weight techniques are commonly used for monitoring forage use on rangelands (Stoddart et al. 1975, Bonham 1989). Forage use estimates provide neither complete nor infallible information on herbivore activities or resource impacts (Cook 1962, Sharp et al. 1994, Laycock 1998,

Research was funded by a grant from The University of Arizona Agriculture Experiment Station. We acknowledge the Coconino National Forest and the Arizona Game and Fish Department for their support of this project. Authors acknowledge Matt Barnes, Alex Connley, Tom DeLiberto, Vicki Gempko, Arlo Halstead, Elizabeth Howery, Dan Koepke, and David Womack for assistance in the field and laboratory. We thank Dr. Mitchel McClaran and 2 anonymous reviewers for reviewing earlier drafts of this paper.

Manuscript accepted 24 Jan. 2000.
Resumen

Los datos acerca de la utilización del forraje pueden ayudar a los manejadores de pastizales y de fauna silvestre a tomar decisiones bien fundamentadas. Sin embargo, los manejadores necesitan saber si las técnicas que comúnmente se utilizan en campo para estimar el uso de forraje de los ungulados producen resultados comparables. El objetivo de este estudio de 2 años fue comparar directamente las medidas de uso de forraje obtenidas mediante el método de parcelas apareadas y 2 métodos de alturapeso (usando curvas de altura-peso y el medidor altura peso preestablecido por el Servicio Forestal de Estados Unidos (USFS). En Junio, Julio y Octubre de 1997 y 1998 medimos el uso del forraje del "Western wheatgrass"(Pascopyrum smithii Rybd.) por el ganado (Bos taurus L.) y por ungulados silvestres, principalmente alce, (Cervus elaphus $\mathbf{L}$.). Las curvas de alturapeso obtenidas en el sitio y el medidor de altura-peso del USFS produjeron estimaciones consistentemente mas bajas (media general $=8$ y $7 \%$ respectivamente) que el método de parcelas apareadas $($ media general $=31 \%$ ). Las estimaciones de alturapeso no difirieron $(\mathbf{P}>0.05)$ cuando se calcularon por las curvas de altura-peso en el sitio o por el medidor del USFS. Dentro de las áreas de muestreo, las estimaciones del método de parcelas apareadas fueron relativamente mas precisas $(\mathrm{CV}$ de la media $=$ $63 \%)$ que las de las curvas en el sitio (CV de la media $=\mathbf{2 3 8 \%}$ ) o que las del medidor del USFS $(\mathrm{CV}$ de la media $=271 \%)$. El apacentamiento selectivo probablemente contribuyó para obtener CV altos en los métodos de altura-peso. Nuestros hallazgos son importantes para los manejadores de pastizales y fauna silvestre porque la técnica de monitoreo de utilización de forraje que ellos usan puede influir en los resultados obtenidos y, consecuentemente, el manejo del apacentamiento y de las decisiones de cosecha de la fauna silvestre. Los manejadores deben asegurarse de escoger la técnica de monitoreo que provee una evaluación apropiada para las metas y objetivos de manejo.

Rasmussen 1998). Forage palatability, relative abundance of forage species, plant growth and morphology, and interspecific differences in foraging behavior may confound forage use estimates obtained by different monitoring techniques (Rechenthin 1956, Cook 1962, Hanley 1982, Zhang and Romo 1995). With so many variables influencing the efficacy of forage monitoring, managers need to know if techniques commonly used to estimate ungulate herbivory under field conditions produce comparable results (Smith and Ruyle 1997).

The paired-plot technique uses protected plots (small grazing exclosures), each paired with a similar unprotected (grazed) plot 
via ocular estimate. The ratios of unprotected and protected clipped dry forage weights are used to calculate percent forage use (Bonham 1989, Interagency Technical Reference 1996). The heightweight technique involves measuring grazed and ungrazed plant heights along a transect and calculating forage use based on height-weight relationships (Interagency Technical Reference 1996). These relationships are established by either clipping ungrazed plants and developing height-weight regression equations for a particular range site and season or by using pre-established USFS height-weight gauges (Interagency Technical Reference 1996). The paired-plot method is considered objective and quantitative but requires considerable time and expense (Klingman et al. 1943). The height-weight technique requires less equipment, and if pre-established height-weight gauges are used, much less time than the paired-plot technique (Interagency Technical Reference 1996). However, the height-weight technique is considered more subjective and qualitative than the paired-plot method (Lomasson and Jensen 1943, Mitchell et al. 1993). Furthermore, some question whether the USFS gauge is appropriate to use across seasons and sites (Mitchell et al. 1993).

Although the pros and cons of the paired-plot and height-weight techniques have been debated, there have been no field experiments that have directly compared whether these techniques provide similar forage use estimates for free-ranging wild and domestic ungulates. The objective of this 2-year study was to compare western wheatgrass (Pascopyrum smithii Rydb.) forage use estimates collected with the paired-plot and 2 heightweight methods (i.e., using on-site heightweight regression curves and the preestablished USFS height-weight gauge) under field conditions.

\section{Materials and Methods}

\section{Study Area}

This study was conducted from March 1997 to October 1998 on the Walker Basin Livestock Grazing Allotment, Coconino National Forest in central Arizona. The Walker Basin Allotment is comprised of about 31,000 ha of private and USFS rangeland. Annual precipitation averages $33 \mathrm{~cm}$ and typically occurs in a bimodal pattern from December to February and July to September (National Oceanographic and Atmospheric Administration 1997). Winter

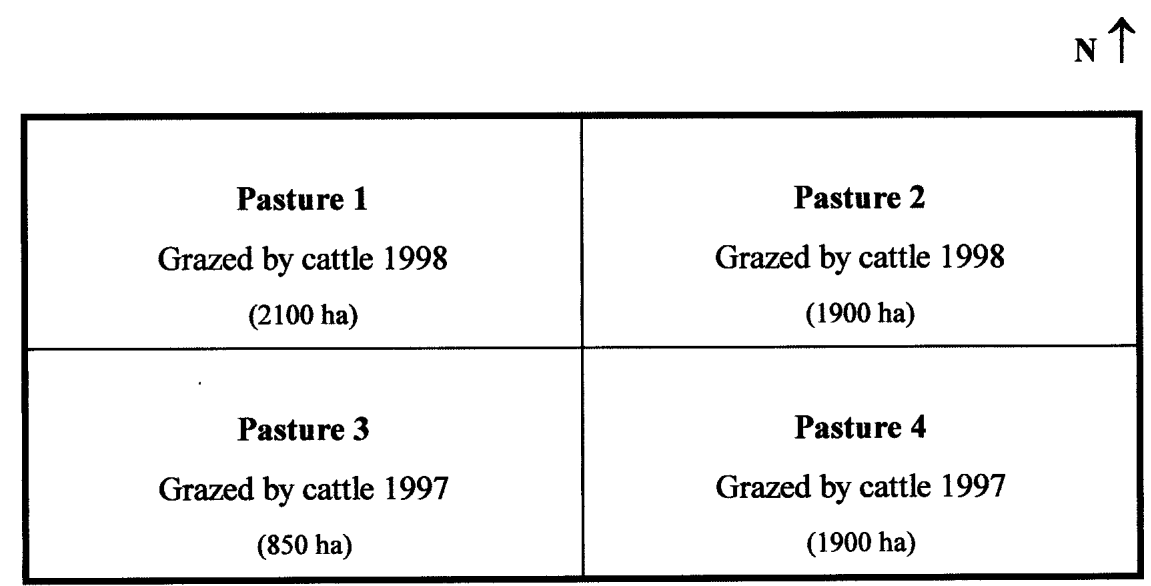

Fig. 1. Pasture layout for the study site on the Walker Basin Allotment, central Arizona, 1997/1998. Cattle grazed southern pastures ( 3 and 4 ) in 1997 and northern pastures (1 and $2)$ in 1998. Elk had access to study pastures year-round.

precipitation is mainly in the form of snow. Our study area (about 6,750 ha) was a pinyon-juniper (Pinus edulis Engelm.Juniperus osteosperma Torr.) savanna with a herbaceous understory dominated by western wheatgrass, the key forage species. The study area consisted of 4 pastures ranging from $850-2,100$ ha in size (Fig. 1). Each year, 2 pastures (hereafter called grazed pastures) were grazed during summer and fall by cattle (Bos taurus L.) and 2 pastures (hereafter called rested pastures) were rested from cattle grazing. Grazed pastures were occupied by 400-450 mature, cross-bred Hereford cows with calves for about 14 days during the growing season. All pastures were subject to year-round grazing by wild ungulates, mainly elk (Cervus elaphus L.).

\section{General Sampling Procedure}

We used the paired-plot and 2 heightweight techniques (Interagency Technical Reference 1996) to evaluate forage use in all pastures 3 times each year: 1) in early/mid-June, immediately-before-cattle entered grazed pastures, 2) in midJune/early July, immediately-after-cattle exited grazed pastures, and 3) in midOctober, at the end of the growing season, about 3 months-after-cattle had left the study area. The grazing schedule allowed us to monitor various levels (13-61\%) of relative (immediately-before and immediately-after-cattle) and total forage use (months-after-cattle) by domestic and wild ungulates. Relative use describes the amount of forage consumed or destroyed up to a certain time during the growing season but prior to peak standing crop (e.g., June or July) (Frost et al. 1994). Total forage use, or simply forage use, is the "proportion of current-year's forage consumed or destroyed by grazing ani- mals," measured at the end of the growing season (Glossary Revision Special Committee 1989).

\section{Year 1 (1997)}

We randomly located 3 sampling areas (about $50 \times 600 \mathrm{~m}$ ) in each pasture with the restriction that they were $\geq 0.4 \mathrm{~km}$ from well-traveled roads, fences and water and $\geq 0.3 \mathrm{~km}$ from each other. Six pairedplot units (protected and unprotected macroplots, $1.7 \mathrm{~m}^{2}$ ea) and 1 heightweight line transect were placed within each sampling area (Fig. 2), for a total of 72 paired-plot units in the entire study area. Seventy-two paired-plot units within the 6,750-ha study area were considered to be the optimum trade-off between the number necessary to provide a quantitative seasonal comparison between the pairedplot and height-weight techniques, and the number of plots that a resource manager could realistically sample within a year. Height-weight transects were about $400 \mathrm{~m}$ long, located between protected and unprotected macroplots and $\geq 10 \mathrm{~m}$ from protected macroplots.

To avoid attracting animals to sampling areas, each protected macroplot was $\geq 100$ $\mathrm{m}$ from the others. Protected and unprotected macroplots were $\geq 50 \mathrm{~m}$ apart and unprotected plots within a paired-plot unit were $\geq 10 \mathrm{~m}$ apart. Two unprotected macroplots, rather than the traditional 1 , were ocularly matched with each protected macroplot to account for possible patch grazing by cattle and elk (Klingman et al. 1943, Grelen 1967). Each unprotected macroplot was marked with 1 wooden stake that protruded about $24 \mathrm{~cm}$ above ground level. To minimize bias due to enhanced growth within protected macroplots (Owensby 1969), 72 new 


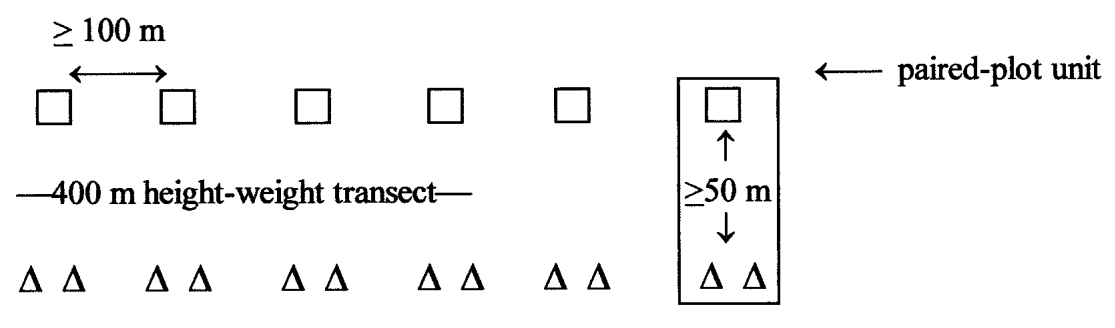

$=$ protected $1.7-\mathrm{m}^{2}$ macroplot (plots $\geq 100 \mathrm{~m}$ apart)

$\Delta \Delta=$ pair of unprotected $1.7-\mathrm{m}^{2}$ macroplots (plots within each pair $\geq 10 \mathrm{~m}$ apart)

Fig. 2. Typical sampling area layout used to estimate forage use with the paired-plot and height-weight techniques, 1997/1998. Each sampling area contained 6 paired-plot units (1 protected and 2 unprotected $1.7-\mathrm{m}^{2}$ macroplots (Klingman et al. 1943)).

paired-plot units were established in March of both years.

Before initially establishing paired-plot units, the precision of ocular pairings was tested by clipping and weighing western wheatgrass from 29 pairs of $0.25-\mathrm{m}^{2}$ circular subplots that were later used to collect forage data (described below). A paired ttest revealed no difference among subplot pairings $(\mathrm{P} \geq 0.2)$. The same observer always selected paired-plot units.

\section{Forage use via the paired-plot tech - nique \\ During each sampling period, we} clipped western wheatgrass from 2 randomly selected paired-plot units in each sampling area (i.e., 6 paired-plot units/pasture/sampling period). A $0.25-\mathrm{m}^{2}$ circular plot frame was used to delineate the $4 \mathrm{sub}$ plots to be clipped within each $1.7-\mathrm{m}^{2}$ macroplot. We averaged the 4 subplot dry weights to obtain 1 mean protected weight for each protected macroplot. For the 2 corresponding unprotected macroplots, we averaged the 8 subplot weights (4 subplots $\mathrm{x} 2$ macroplots) to obtain 1 mean unprotected weight. Percent use for a paired-plot unit was calculated as the ratio of mean unprotected and protected dry weights. Negative utilization values from subplots were zeroed (Werner and Urness 1998). Mean percent use for a sampling area was calculated from the 2 randomly selected paired-plot units. Mean percent use for a pasture was calculated from the 3 sampling areas in that pasture.

\section{Forage use via the height-weight techniques}

Height-weight sampling occurred concurrently with paired-plot sampling and followed guidelines as outlined in the Interagency Technical Reference (1996).
During each sampling period, we measured average heights of 60 western wheatgrass plants along a $400-\mathrm{m}$ transect ( 1 transect/sampling area $=3 /$ pasture $)$. About every $3 \mathrm{~m}$, the grazed or ungrazed western wheatgrass plant nearest the observer's toe was measured. A plant was defined as the vegetation occupying a circle of turf at least 2 inches in diameter. Each sampling period, 10 ungrazed western wheatgrass plants per sampling area were clipped to develop 36 on-site heightweight curves. We used these heightweight curves to estimate forage use for each transect. Forage use was also estimated along each transect with the pre-established USFS culmless western wheatgrass height-weight gauge. Mean use for a pasture was calculated from the 3 sampling areas with both techniques. Finally, each year's immediately-before-cattle, immediately-after-cattle, and months-after-cattle on-site height-weight curves from each sampling area were combined and compared to the pre-established USFS heightweight gauge curve (Fig. 4).

\section{Year 2 (1998)}

Forage use via the paired-plot technique In 1998, the paired-plot sampling procedure was altered slightly to address high standard errors (range $=0-35 \%$ ) for 1997 subplot use estimates within sampling areas. Three subsamples were taken in each paired-plot unit by ocularly matching $0.25-\mathrm{m}^{2}$ subplots. We ocularly matched three, $0.25-\mathrm{m}^{2}$ subplots within a protected macroplot to three, $0.25-\mathrm{m}^{2}$ subplots within each of the 2 unprotected macroplots. Percent use for a subsample was the ratio of dry weights clipped from the 2 unprotected $0.25-\mathrm{m}^{2}$ subplots (averaged) and the corresponding $0.25-\mathrm{m}^{2}$ protected subplot. Percent use for a paired-plot unit was the mean of the 3 matched subsample use estimates. Means for sampling areas and pastures were calculated as described in 1997.

\section{Forage use via the height-weight tech - niques}

Methodology used for the height-weight transect was the same as in 1997. However, 1997 paired-plot use estimates were consistently higher $(\mathrm{P}<0.0001, \mathrm{n}=$ 36) than height-weight use estimates (Halstead et al. 1998). This discrepancy may have been due to herbivores being attracted to the wooden stakes used to delineate unprotected macroplots. If animals were attracted to stakes, this could have led to higher use within unprotected macroplots than along height-weight transects and help explain the difference between paired-plot and height-weight forage use estimates. We tested this hypothesis by applying the height-weight method (with on-site curves) to 60-point transects within unprotected macroplots. Each sampling period, the heights of 30 western wheatgrass plants were measured within each of the 4 unprotected macroplots scheduled to be clipped within a sampling area (two, 60-point macroplot transects/sampling area). Heights of grazed or ungrazed plants were systematically measured at $15-\mathrm{cm}$ intervals within the 4 macroplots. In each sampling area, we compared mean use from the 2 macroplot height-weight transects to the mean use calculated from the $400-\mathrm{m}$ height-weight line transect.

\section{Statistical Analysis}

We used a $3 \times 3 \times 4$ factorial analysis of variance (ANOVA) to examine differences across forage use techniques (paired-plot, on-site height-weight, and USFS height-weight), sampling periods, and pastures. Variances were unequal for the height-weight and paired-plot forage use estimates. Therefore, the arc-sine transformation was applied to forage use data prior to analysis as recommended by Steel and Torrie (1980) for percentage data. A 2 x 4 ANOVA was used to detect differences among use estimates from line and macroplot height-weight transects between locations (line vs macroplot transects) and among pastures. When F-tests were significant $(\mathrm{P}<0.05)$, LSD tests were used to detect differences among means $(\mathrm{P}<0.05)$. Coefficients of variation were calculated for each technique within sampling areas as an indicator of technique precision. 


\section{Results}

\section{Paired-Plot vs Height-Weight} Techniques

The paired-plot technique produced significantly higher $(\mathrm{P}<0.05)$ use estimates than either of the 2 height-weight techniques across all pastures (Fig. 3). Compared across pastures and sampling periods, paired-plot estimates were about 23 percentage points (or about 4 times) higher than height-weight estimates using on-site curves and the USFS gauge (Fig. 3).

Matching individual subplots within macroplots in 1998 did not reduce standard errors of paired-plot estimates within sampling areas (SE range $=0-35 \%$ and 0 $36 \%$ in 1997 and 1998, respectively). Standard errors within sampling areas for height-weight techniques were relatively lower than paired-plot estimates both years (SE range $=0-3 \%$ and $0-6 \%$ in 1997 and 1998, respectively). However, lower standard errors for the height-weight techniques were a function of their lower means relative to the paired-plot technique. Mean coefficients of variation within sampling areas were higher for on-sight height-weight curves $(\mathrm{CV}=238 \%)$ and the USFS gauge $(\mathrm{CV}=271 \%)$ than for the paired-plot technique $(\mathrm{CV}=63 \%)$. Selective grazing, a common occurrence on light- to moderately-stocked ranges, evidently contributed to higher CVs for the height-weight techniques. For example, a few individual plants measured along height-weight transects were typically heavily-grazed (up to $82 \%$ use), however, the majority of plants were either ungrazed or lightly-grazed.

The effect of sampling period on forage use estimates was significant $(P<0.001)$. Immediately-after-cattle use estimates were generally higher (mean $=21 \pm 3$ (SEM) percentage points) than immediately-before-cattle (mean $=9 \pm 3$ (SEM) percentage points) and months-after-cattle (mean $=16 \pm 3$ (SEM) percentage points) use estimates with all techniques ( $\mathrm{P}<$ $0.05)$. This difference was expected because immediately-after-cattle use estimates were made 1-2 days after cattle had exited grazed pastures and around the mid-point of the growing season (i.e., before any regrowth had occurred and before total forage production had been achieved).

Bork and Werner (1999) suggested that zeroing "negative" paired-plot data between protected and unprotected plots as done in our study inflates forage use estimates on spatially heterogeneous ranges. Zeroed paired-plot data in our

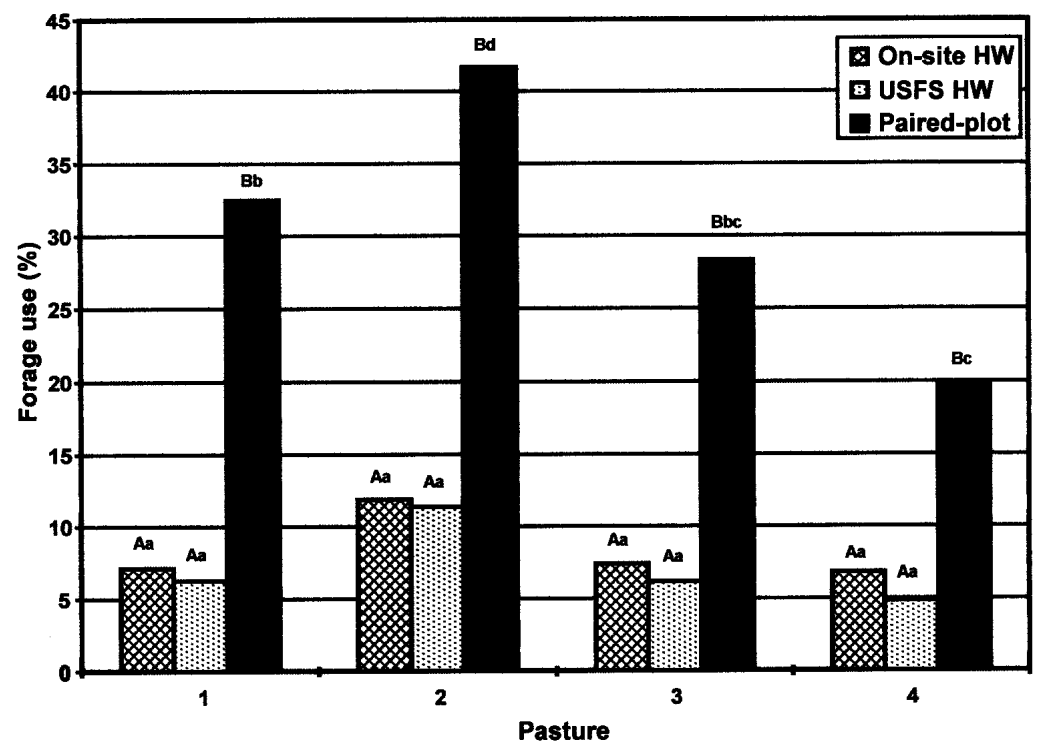

Fig. 3. Western wheatgrass use $(\%)$ in 4 pastures measured using on-site height-weight $(\mathrm{HW})$ curves, the USFS height-weight gauge, and the paired-plot technique, averaged over 1997 and 1998. Pasture means with the same upper case letters are not significant at $P \leq 0.05$. Technique means across pastures with the same lowercase letters are not significant at $P \leq$ 0.05. Analysis of variance was performed on arc-sine transformed data, however, actual percent forage use data are presented for ease of interpretation. study were about 9 percentage points higher than non-zeroed paired-plot data $(\mathrm{P}$ $<0.0001, \mathrm{n}=72$; Wilcoxon signed rank test). However, non-zeroed paired-plot estimates were still about 12 percentage points higher than use estimates obtained with either of the 2 height-weight techniques $(\mathrm{P}<0.0001)$.

\section{On-Site Height-Weight Curves vs the USFS Gauge}

On-site height-weight curves fluctuated with plant phenological development: months-after-cattle curves showed proportionately more weight in the lower half of plants than immediately-before-cattle or immediately-after-cattle curves (Fig. 4, showed a more linear relationship than onsite curves (Fig. 4, Table 1). However, mean use calculated with the USFS gauge did not differ $(\mathrm{P}>0.05)$ from forage use calculated with on-site curves in any pasture (Fig. 3) or during any sampling period.

\section{Line vs Macroplot Height-Weight Transects}

There was no significant difference between line and macroplot height-weight transect estimates $(P=0.23)$, indicating herbivores were not attracted to the unprotected macroplots marked by wooden stakes.
Table 1). The USFS gauge curve generally

Table 1. Third-order polynomial regression equations and $\mathbf{r}^{2}$-values for 6 on-sight height-weight curves, and the USFS height-weight gauge curve for culmless western wheatgrass. On-site curves were developed for 3 sampling periods (immediately-before-cattle or IBC, immediately-after-cattle or IAC, and months-after-cattle or MAC) in 1997 and 1998 in central Arizona. Sampling periods were early/mid-Jun. (IBC), mid-Jun./early Jul. (IAC), and mid-Oct. (MAC). See Figure 4 for height-weight graphs.

\begin{tabular}{llc}
\hline \hline Curve, Year & \multicolumn{1}{c}{ Regression equation } & $\mathrm{r}^{2}$ \\
\hline IBC, 1997 & $\mathrm{y}=0.0997 \mathrm{x}^{3}-0.9213 \mathrm{x}^{2}+9.1949 \mathrm{x}+0.875$ & 0.9999 \\
IAC, 1997 & $\mathrm{y}=0.0528 \mathrm{x}^{3}-0.2861 \mathrm{x}^{2}+7.4149 \mathrm{x}+2.2889$ & 0.9996 \\
MAC, 1997 & $\mathrm{y}=0.1621 \mathrm{x}^{3}-1.253 \mathrm{x}^{2}+6.3614 \mathrm{x}-0.0194$ & 0.9999 \\
IBC, 1998 & $\mathrm{y}=0.0996 \mathrm{x}^{3}-0.7972 \mathrm{x}^{2}+8.1091 \mathrm{x}-0.3697$ & 0.9997 \\
IAC, 1998 & $\mathrm{y}=0.1209 \mathrm{x}^{3}-1.1111 \mathrm{x}^{2}+8.6832 \mathrm{x}+4.2499$ & 0.9994 \\
MAC, 1998 & $\mathrm{y}=0.1709 \mathrm{x}^{3}-1.5511 \mathrm{x}^{2}+8.496 \mathrm{x}-0.6955$ & 0.9997 \\
USFS & $\mathrm{y}=-0.1329 \mathrm{x}^{3}+3.037 \mathrm{x}^{2}-8.1332 \mathrm{x}+10.55$ & 0.9987 \\
\hline
\end{tabular}


(4)

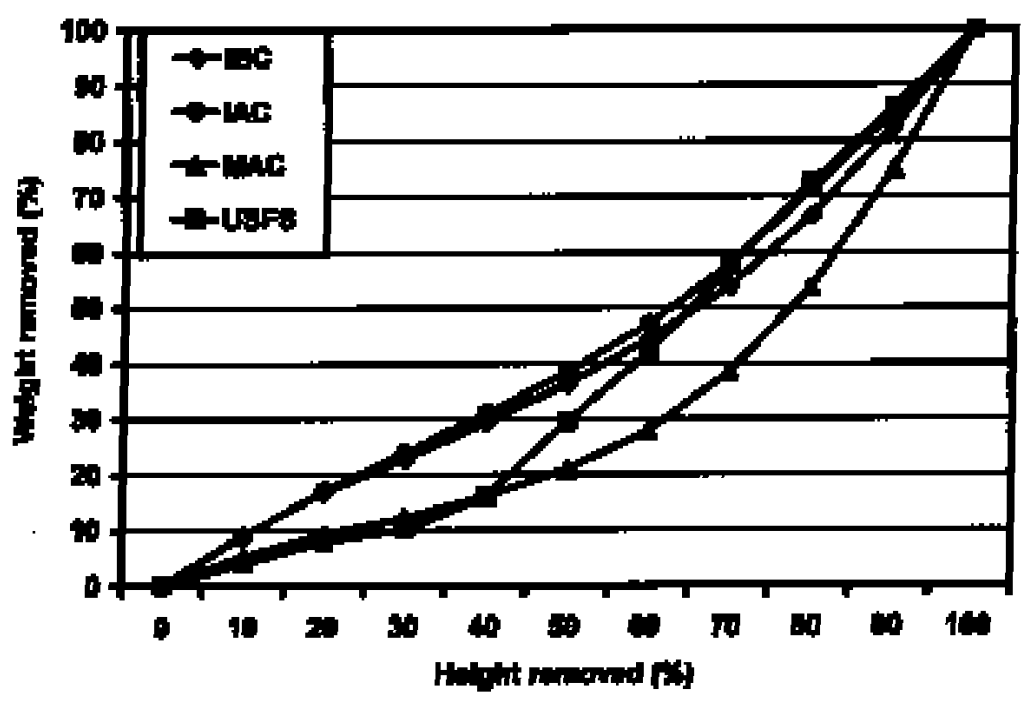

(ㅇ)

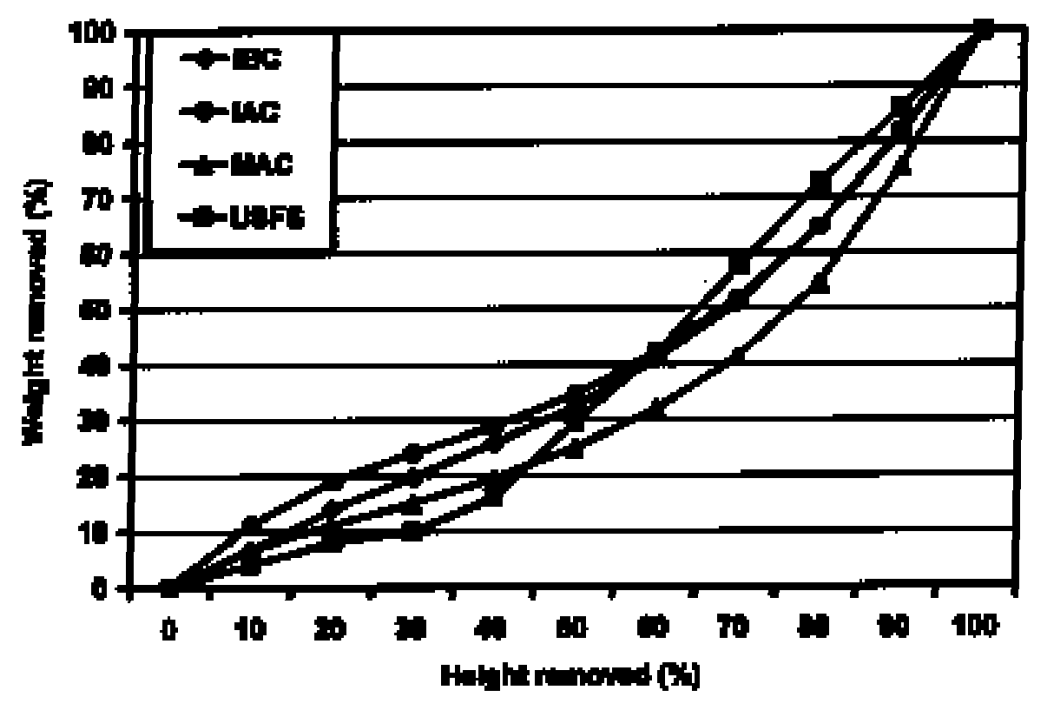

Fig. 4. On-site height-weight curves vs the USFS height-weight gauge curve for culmless western wheatgrass for 3 sampling periods (immediately-before-cattle or IBC, immediately-after-cattle or IAC, and months-after-cattle or MAC) in 1997 (a) and 1998 (b) in central Arizona. Sampling periods were early/mid-Jun. (IBC), mid-Jun./early Jul. (IAC), and mid-Oct. (MAC). See Table 1 for regression equations and $\mathbf{r}^{2}$-values.

\section{Discussion}

\section{Paired-Plot vs Height-Weight Techniques}

Differences in forage use estimates obtained with the paired-plot and the 2 height-weight methods were substantial. The paired-plot technique consistently produced higher use estimates than either of the 2 height-weight techniques across with allometric utilization monitoring techniques, in accurately converting height remaining to weight removed (Bonham 1989, Mitchell et al. 1993, Laycock 1998). The height-weight technique does not account for the selective way that most ungulates graze individual plants (McKinney 1997). Ungulates typically remove only some of a plant's leaves or tillers which results in a single plant of varying heights (McKinney 1997). However, the height-weight model assumes that herbivores "clip" all parts of a single plant to the same height (Reid and Pickford 1941). To illustrate, assume half of a plant has been grazed to the ground while the other half is left ungrazed. Following the height-weight methodology (Interagency Technical Reference 1996), the plant would be recorded as having $50 \%$ of its height removed, as if the entire plant had been grazed to half its height. Based on western wheatgrass heightweight curves, $50 \%$ height removed is equivalent to about 35\% utilization (Fig. 4). However, because proportionally more weight is in the lower portion of the plant (and was removed on the grazed half), the hypothetical plant has actually had about $50 \%$ of its weight removed $(50 \%$ utilization). This bias would ostensibly occur more on lightly to moderately-stocked ranges (as in our study; Fig. 3) than on heavily-stocked ranges because animals tend to be less selective (i.e., graze more uniformly) on heavily-stocked ranges (Holechek et al. 1998). Three-dimensional height-volume relationships more accurately predict forage production than 2dimensional height-weight regression equations (Johnson et al. 1988) and may also more accurately assess forage removed. However, quantifying the volume of the specific sections removed from individual plants (e.g., lighter upper sections vs heavier lower sections) would be prohibitively cumbersome for management purposes.

The paired-plot method may overestimate forage use if cages create microclimates that enhance forage growth (Owensby 1969, Sharrow and Motazedian 1983). Microclimates may arise when perching birds "fertilize" exclosures, in years with above average precipitation, or when exclosures are not moved each year, allowing more than 1-year's production to accumulate (Grelen 1967, Owensby 1969, Sharrow and Motazedian 1983). We addressed the latter concern by moving cages at the beginning of each growing season so that they protected forage for $\leq$ 7 months. However, this effort did not pre- 
clude the possibility of enhanced growth within protected plots, especially in 1998, when precipitation was higher as evidenced by greater western wheatgrass standing crop and stubble heights (Halstead 1998). For example, during 1998, western wheatgrass standing crop averaged about $131 \mathrm{~kg} \mathrm{ha}^{-1} \pm 18$ (SEM) higher and stubble heights averaged about $3 \mathrm{~cm} \pm 1$ (SEM) higher than in 1997 (Halstead 1998).

\section{On-Site Height-Weight Curves vs the USFS Gauge}

Forage use estimates made with on-site height-weight curves and the pre-established USFS height-weight gauge were remarkably similar across pastures (Fig. 3) and sampling periods. Mitchell et al. (1993) concluded that height-weight curves changed statistically with phenological development and location. However, their analysis was conducted on height-weight regressions and not on use estimates derived from those equations. On-site height-weight curves in this study changed across time (Fig. 4), but not enough to produce use estimates different from those calculated with the pre-established USFS gauge. Time required to develop height-weight curves made forage use calculation with on-site curves slower than with the USFS gauge. However, data from this study suggest developing western wheatgrass height-weight curves for a particular site or season may be unnecessary. Other researchers have indicated that height-weight relationships for other forage species on the same range site are fairly consistent across years (Heady 1950, McDougald and Platt 1976). Nevertheless, those monitoring other forage species or dissimilar sites should field check on-site height-weight curves against the USFS gauge before using pre-established gauges to calculate forage use.

\section{Conclusions and Management Implications}

The primary goal of this study was to directly compare 3 forage use techniques under field conditions commonly encountered by land managers on arid and semiarid rangelands (i.e., seasonal, irregular grazing by more than one large ungulate species in a heterogeneous, patchy environment). Technique accuracy was not addressed because such studies typically involve an artificial population and simulated herbivory (e.g., mowing or clipping) which would have negated our ability to quantify the selective way that free-ranging ungulates graze under field conditions.

The paired-plot technique consistently produced higher forage use estimates than both height-weight techniques across all pastures and sampling periods during both years of the study. On the other hand, onsite and pre-established USFS western wheatgrass curves consistently produced similar forage use estimates. We believe the differences among the paired-plot and height-weight techniques, and the similarities between the height-weight techniques are real for western wheatgrass in central Arizona because of the consistency of results.

As this study showed, popular forage use monitoring techniques can produce different results on the same range site. Managers should consider that different forage use techniques might produce different estimates, and if used alone, will result in different grazing and wildlife management decisions. The monitoring technique(s) chosen must address the resource objectives that are formulated in management plans. If it is important to know the relative or total percentage of current-year's growth removed by herbivores on a management unit for a particular season or year, forage use techniques might be used with the caveat that the paired-plot technique may result in higher use estimates than height-weight techniques.

Effective rangeland management does not always require, or does not only require, measurements of forage use. In some situations, residual vegetation data (e.g., stubble height) may provide more useful information than forage use data (Smith 1998, Scarnecchia 1999) because it is correlated with erosion protection, soil moisture retention, forage regrowth potential, and small animal and insect habitat (Papanastasis 1985, Hall and Lindenmuth 1998, Holechek et al. 1998). Stubble height data can be collected simultaneously with height-weight data and has the advantage of directly and quantitatively assessing plant material left after grazing (Hall and Lindenmuth 1998). Use pattern maps (e.g., stubble height and/or heightweight data) coupled with relevant trend data (e.g., plant species composition, herbaceous and shrub cover, vegetation structure) can help managers to more comprehensively evaluate management strategies. More complex resource issues (e.g., management of threatened or endangered species) may require more intensive monitoring programs.

\section{Literature Cited}

Bonham, C. D. 1989. Measurements for terrestrial vegetation. John Wiley and Sons, New York, N.Y

Bork, E. W. and S. J. Werner. 1999. Viewpoint: implications of spatial variability for estimating forage use. J. Range Manage. $52: 151-156$

Cook, C. W. 1962. An evaluation of some common factors affecting utilization of desert range species. J. Range Manage. 15:333-338.

Frost, W. E., E. L. Smith, and P. R. Ogden. 1994. Utilization guidelines. Rangelands 16 : 256-259.

Glossary Revision Special Committee. 1989. A glossary of terms used in range management $3^{\text {rd }}$ ed. Soc. Range Manage., Denver, Colo.

Grelen, H. E. 1967. Comparison of cage methods for determining utilization on pinebluestem range. J. Range Manage. 20:94-96.

Hall, F. C. and R. Lindenmuth. 1998. Developing and achieving management objectives on National Forest System lands, p. 47-49. In: Stubble height and utilization measurements: uses and misuses. Oregon State Univ. Agr. Expt. Sta., Corvallis, Ore.

Halstead, L. E. 1998. Monitoring elk and cattle forage utilization under a specialized grazing system in Arizona. M.S. Thesis, Univ. Arizona, Tucson, Ariz.

Halstead, L. E., L. D. Howery, G. B. Ruyle, and P. R. Krausman. 1998. Comparison of the paired-plot and height-weight methods for measuring forage use. Abstr. 51st Ann. Meeting Soc. Range Manage. Guadalajara, Jalisco, Mex. 51:31.

Hanley, T. A. 1982. The nutritional basis for food selection by ungulates. J. Range Manage. 35:146-151.

Heady, H. F. 1950. Studies on bluebunch wheatgrass in Montana and height-weight relationships of certain range grasses. Ecol. Monog. 20:56-80.

Holechek, J., R. D. Pieper, and C. H. Herbel. 1998. Range management, principles and practices, 3rd ed. Prentice Hall, Upper Saddle River, N.J.

Interagency Technical Reference. 1996. Utilization studies and residual measurements. BLM National Appl. Resour. Sci. Center. Coop. Ext. Ser., USFS, NRCS, BLM.

Johnson, P. S., C. L. Johnson, and N. E. West. 1988. Estimation of phytomass for ungrazed crested wheatgrass plants using allometric equations. J. Range Manage. 41:421-425.

Klingman, D. L., S. R. Miles, and G. O. Mott. 1943. The cage method for determining consumption and yield of pasture herbage. J. Amer. Soc. Agron. 35:739-746.

Laycock, W. A. 1998. Variation in utilization estimates caused by differences among methods, years, and observers, p. 17-24. In: Stubble height and utilization measurements: uses and misuses. Oregon State Univ. Agr. Expt. Sta., Corvallis, Ore. 
Lomasson, T. and C. Jensen. 1943. Determining use of grasses from heightweight tables. J. Forest. 41:589-593.

McDougald, N. K. and R. C. Platt. 1976. A method of determining utilization for wet mountain meadows on the Summit allotment, Sequoia National Forest, California. J. Range Mange. 29:497-501.

McKinney, E. 1997. It may be utilization, but is it management? Rangelands 19:4-7.

Mitchell, J. E., R. E. Elderkin, and J. K. Lewis. 1993. Seasonal height-weight dynamics of western wheatgrass. J. Range Manage. 46:147-151.

National Oceanic and Atmospheric Administration. 1997. Climatological data annual summary Arizona. Nat. Environ. Satellite, Data and Info. Serv., Nat Climatic Data Ctr., Vol. 101(13), Asheville, N.C.

Owensby, C. E. 1969. Effect of cages on herbage yield in true prairie vegetation. J. Range Manage. 22:131-132.

Papanastasis, V. P. 1985. Stubble height, basal cover, and herbage production relationships in grasslands of northern Greece. J. Range Manage. 38:247-250.
Rasmussen, G. A. 1998. Interpretation of utilization and long-term frequency measurements for rangeland management, p. 25-28. In: Stubble height and utilization measurements: uses and misuses. Oregon State Univ. Agr. Expt. Sta., Corvallis, Ore.

Rechenthin, C. A. 1956. Elementary morphology of grass growth and how it affects utilization. J. Range Manage. 9:167-170.

Reid, E. H. and G. D. Pickford. 1941. A comparison of the ocular-estimate-by-plot and the stubble-height methods of determining percentage utilization of range grasses. J. Forest. 39:933-941.

Scarnecchia, D. L. 1999. Viewpoint: the range utilization concept, allocation arrays, and range management science. J. Range Manage. 52:157-160.

Sharp, L., K. Sanders, and N. Rimbey. 1994. Management decisions based on utilizationis it really management? Rangelands 16:38-40.

Sharrow, S. H. and I. Motazedian. 1983. A comparison of three methods for estimating forage disappearance. J. Range Manage. $36: 469-471$
Smith, E. L. 1998. Seasonal effects on the measurement and interpretation of utilization, p. 9-16. In: Stubble height and utilization measurements: uses and misuses. Oregon State Univ. Agr. Expt. Sta., Corvallis, Ore.

Smith, E. L. and G. B. Ruyle. 1997. Considerations when monitoring rangeland vegetation, p. 1-6. In: G. B. Ruyle (ed.), Some methods for monitoring rangelands and other natural area vegetation. USDA Coop. Ext. Rep. 9043, Univ. Arizona, Tucson, Ariz.

Steel, R. G. D. and J. H. Torrie. 1980. Principles and procedures of statistics, a biometrical approach, 2nd ed. McGraw Hill Book Co., New York, N.Y.

Stoddart, L. A., A. D. Smith, and T. W. Box. 1975. Range management, 3rd ed. McGraw Hill Book Co., New York, N.Y.

Werner, S. J. and P. J. Urness. 1998. Elk forage utilization within rested units of restrotation grazing systems. J. Range Manage. 51:14-18.

Zhang, J. and J. T. Romo. 1995. Impacts of defoliation on tiller production and survival in northern wheatgrass. J. Range Manage. $48: 115-120$. 